\title{
Biosynthesis of silver nanoparticles using Caesalpinia ferrea (Tul.) Martius extract: physicochemical characterization, antifungal activity and cytotoxicity
}

\author{
Mônica R P Senra ${ }^{1}$, Rafael 0 Corrêa ${ }^{1}$ ， Pedro Henrique Stroppa ${ }^{2}$, Flàvia Campos Marques ${ }^{2}$, Gustavo F S \\ Andrade $^{2}$, Charlane Chimini Corrêa $^{2}$, Marcos Antônio F Brandão ${ }^{1}$, Nádia R B Raposo ${ }^{\text {Corresp. } 1}$ \\ 1 Núcleo de Pesquisa e Inovação em Ciências da Saúde (NUPICS) - Faculdade de Farmácia, Universidade Federal de Juiz de Fora, Juiz de Fora, Brazil \\ 2 Departamento de Química, Universidade Federal de Juiz de Fora, JUIZ DE FORA, MINAS GERAIS, Brazil \\ Corresponding Author: Nádia R B Raposo \\ Email address: nadiacritt@gmail.com
}

Background. Green synthesis is an ecological technique for the production of well characterized 45 metallic nanoparticles using plants. This study investigated the synthesis of silver nanoparticles (AgNPs) using a Caesalpinia ferrea seed extract as a reducing agent. Methods. The formation of AgNPs was identified by instrumental analysis, including ultraviolet-visible (UV-Vis) spectroscopy, scanning electron microscopy (SEM), Xray diffraction (XRD) of the AgNPs, and surface-enhanced Raman scattering (SERS) spectra of rhodamine-6G (R6G). We studied the physicochemical characterization of AgNPs, evaluated them as an antifungal agent against Candida albicans, Candida kruzei, Candida glabrata and Candida guilliermondii, and estimated their minimum inhibitory concentration (MIC) and minimum fungicidal concentration (MFC) values. Lastly, this study evaluated the cytotoxicity of the AgNPs in murine L929 fibroblasts cells using an MTT assay. Results. The UV-Vis spectroscopy, SERS, SEM, and XRD results confirmed the rapid formation of spheroidal 30-50-nm AgNPs. The MIC and MFC values indicated the antifungal potential of AgNPs against most of the fungi studied and high cell viability in murine L929 fibroblasts. In addition, this study demonstrated that $C$. ferrea seed extracts may be used for the green synthesis of AgNPs at room temperature for the treatment of candidiasis. 
Article

Biosynthesis of silver nanoparticles using Caesalpinia ferrea (Tul.) Martius extract: physicochemical characterization, antifungal activity and cytotoxicity

Mônica R P Senra ${ }^{1}$, Rafael O Corrêa ${ }^{1}$, Pedro Henrique Stroppa ${ }^{2}$, Flávia Campos Marques ${ }^{2}$, Gustavo F S Andrade ${ }^{2}$, Charlane Chimini Correa ${ }^{2}$, Marcos Antônio F Brandão ${ }^{1}$ and Nádia R B Raposo ${ }^{1, *}$

1 Núcleo de Pesquisa e Inovação em Ciências da Saúde (NUPICS), Faculdade de Farmácia, Universidade Federal de Juiz de Fora, Juiz de Fora-MG, Brazi

2 Departamento de Química, Instituto de Ciências Exatas, Universidade Federal de Juiz de Fora, Juiz de Fora-MG, Brazil.

*Corresponding author:

Nádia Raposo ${ }^{1}$

nadiacritt@gmail.com; Tel.: +55-32-2102-3809

Academic Editor: name

Received: date; Accepted: date; Published: date 


\section{Abstract}

Background. Green synthesis is an ecological technique for the production of well characterized metallic nanoparticles using plants. This study investigated the synthesis of silver nanoparticles (AgNPs) using a Caesalpinia ferrea seed extract as a reducing agent.

Methods. The formation of AgNPs was identified by instrumental analysis, including ultraviolet-visible (UV-Vis) spectroscopy, scanning electron microscopy (SEM), X-ray diffraction (XRD) of the AgNPs, and surface-enhanced Raman scattering (SERS) spectra of rhodamine-6G (R6G). We studied the physicochemical characterization of AgNPs, evaluated them as an antifungal agent against Candida albicans, Candida kruzei, Candida glabrata and Candida guilliermondii, and estimated their minimum inhibitory concentration (MIC) and minimum fungicidal concentration (MFC) values. Lastly, this study evaluated the cytotoxicity of the AgNPs in murine L929 fibroblasts cells using an MTT assay.

Results. The UV-Vis spectroscopy, SERS, SEM, and XRD results confirmed the rapid formation of spheroidal 30-50-nm AgNPs. The MIC and MFC values indicated the antifungal potential of AgNPs against most of the fungi studied and high cell viability in murine L929 fibroblasts. In addition, this study demonstrated that $C$. ferrea seed extracts may be used for the green synthesis of AgNPs at room temperature for the treatment of candidiasis. 


\section{Introduction}

Antimicrobial resistance is a phenomenon of infectious microbial flora that aids them in resisting antimicrobial agents to which they were previously sensitive (Lakum, Shah \& Chikhalia, 2014). The occurrence of antifungal multi-drug resistant infections, which affects the public health worldwide, has been increasing to alarming levels and has stimulated investigations on plant species for the treatment of candidiasis. Microorganisms of the genus Candida have acquired resistance to a variety of antifungal drugs, leading to poor treatment, and increasing disease severity. Hence, studies on new pharmacologically active compounds for the treatment of fungal conditions are warranted (Morais-Braga et al., 2016).

Recent advances in nanoscience and nanotechnology have radically changed the way we diagnose, treat, and prevent various diseases in all aspects of human life. Silver nanoparticles (AgNPs) are one of the most vital nanomaterials among several metallic nanoparticles that are involved in biomedical applications (Wei et al., 2014; Zhang et al., 2016). They also show antimicrobial activity making them applicable to different areas of medicine with the potential to combat the proliferation of microorganisms and yeasts (Dúran et al., 2010; Iravani, 2011; Vasquez-Munoz, Avalos-Borja \& Castro-Longoria, 2014; Jacometo et al., 2015; Szweda et al., 2016; Das et al., 2016). However, there is a growing need for developing environmentally friendly processes of synthesis of nanoparticles that do not use toxic chemicals (Song \& Kim, 2009).

Biological methods of synthesis of nanoparticles using microorganisms (Castro-Longoria, Vilchis-Nestor \& Avalos-Borja, 2011; Geronikaki et al., 2013; Xue et al., 2016), enzymes (Jacometo et al., 2015), and plant or plant extracts (Iravani, 2011; Mallmann et al., 2015; Kubyshkin et al., 2016; Shaik et al., 2017) have been suggested as ecofriendly alternatives to chemical and physical methods. Using plant extracts for synthesis of nanoparticles can be advantageous over other biological processes by eliminating the elaborate process of maintaining cell cultures (Iravani, 2011). It can also be suitably scaled up for large-scale synthesis of nanoparticles (Song \& Kim, 2009). Plant species have been used for biosynthesis of nanoparticles to preserve the antimicrobial activity of AgNPs, reducing its toxic effects on human cell lines, and increasing its practical application without impacting on the environment (Dúran et al., 2010; Iravani, 2011). Plant extracts function as bioreducers besides having nanoparticle stabilizers in colloidal solutions of metals, such as silver and gold. AgNPs are easy 
107 to prepare and chemically modified by reduction of photochemical, radiolytic, or biogenic ions 108 or formations (Xue et al., 2016).

109 Brazil has an advantage in this market because it has the greatest biodiversity in the world and a genetic heritage of great potential for the development of new drugs (Yunes, Pedrosa \& Cechinel Filho, 2001; Dutra et al., 2016). In the Amazon, there are approximately 25-30,000 species, but less than $1 \%$ of the Brazilian plant species have been was investigated from the chemical and pharmacological point of view (Yunes, Pedrosa \& Cechinel Filho, 2001; Araújo et al., 2014; Oliveira et al.; 2014; Kobayashi et al., 2015; Dutra et al., 2016).

Among the plant species of the Brazilian biome, Caesalpinia ferrea (Tul.) Martius is popularly referred to as ironwood or jucá, and the traditional pharmacological applications of shells, seeds, roots, and fruits from this species are used to heal wounds and bruises (Cavalheiro et al., 2009; Bariani et al., 2012; Silva et al., 2015). Accordingly, anti-inflammatory (Araújo et al., 2014; Kobayashi et al., 2015), antifungal (Bariani et al., 2012), antihistaminic, antiallergic, anticoagulant, and larvicidal activities (Cavalheiro et al., 2009)], and antiproliferative, cytoprotective, and antimutagenic effects have been shown (Silva et al., 2015).

In this research, we investigated the synthesis of silver nanoparticles (AgNPs) using a Caesalpinia ferrea seed extract as a reducing agent for the treatment of candidiasis. The formation of AgNPs was identified by instrumental analysis and results confirmed the rapid formation of spheroidal 30-50-nm AgNPs. In addition, the impact of green-fabricated AgNPs on Candida spp and cell viability in murine L929 fibroblast cells was assessed.

\section{Materials and Methods}

\subsection{Preparation of the seed extract}

Seeds of Caesalpinia ferrea (tul.) Martius were acquired at the "Ver-O-Peso" market in Belem, Pará, Brazil (Latitude 01270210 0S and Longitude 48300160 OW). Extract was obtained by macerating $25 \mathrm{-g}$ seeds in $70 \%(\mathrm{v} / \mathrm{v})$ ethanol for $72 \mathrm{~h}$ in the dark. Extract was filtered under low pressure (Rotavapor® R-210, Buchi, Switzerland), were lyophilized (ALPHA 1-4 ID plus, Christ, Germany) under 1.8 -mBar pressure at $-14^{\circ} \mathrm{C}$, and was then maintained at room temperature in the dark until use.

\subsection{Biosynthesis of AgNPs with extract of Caesalpinia ferrea}

Stock solution of $C$. ferrea extract was prepared by solubilizing $50 \mathrm{mg}$ of lyophilized powder in $50 \mathrm{~mL}$ of ethanol $70 \%(\mathrm{v} / \mathrm{v})$, and then it was sonicated for 10 minutes. For the formation of AgNPs by green synthesis, $10 \mu \mathrm{L}$ of C. ferrea stock solution was added into 990 
$145 \mu \mathrm{L}$ of a silver nitrate solution ( $3 \mathrm{mM}-\mathrm{AgNO}_{3}$ - Synth, São Paulo, Brazil) and $0.5 \mu \mathrm{L}$ of sodium 146 hydroxide (5M - NaOH - Synth, São Paulo, Brazil). The reaction mixture passed light yellow to 147 color brown immediately indicating the formation of the AgNPs, the process was carried out at 148 room temperature.

149 In order to confirm the formation of the AgNPs, measurements of absorption of reaction 150 aliquots were performed immediately after and at intervals of $12 \mathrm{~h}$ to $96 \mathrm{~h}$ using a spectrometer 151 (Multiskan GO Microplate Spectrophotometer, Canada, USA). All measurements showed

152

153

154

155

156

157

158

159

160

161

162

163

164

165

166

167

168

169

170

171

172 maximum absorption near $423 \mathrm{~nm}$ (see Figure 1).

\section{3. Nanoparticle characterization}

\section{Ultraviolet-visible (UV-vis) spectroscopy}

UV-vis spectra were obtained by a Shimadzu UV-1800 spectrophotometer with $1 \mathrm{~cm}$ path length quartz cell. After mixing the seed C.férrea extract with $\mathrm{AgNO}_{3}$ and $\mathrm{NaOH}$ solutions, the color changed from yellow to brown. The formation of AgNPs was determined by UV-vis measurements, where aliquots of the reaction, see section 3.2, were analyzed at intervals of every 12 hours for $96 \mathrm{~h}$. UV-vis spectroscopy showed a Plasmon resonance centered at $423 \mathrm{~nm}$ (Fig 1).

\section{Scanning Electron Microscopy (SEM)}

Scanning electron microscopy (SEM) measurements were obtained using a FEI microscope, model Quanta 250, working at 25 or $30 \mathrm{kV}$ in the $\mathrm{W}$-filament. The colloidal solution was deposited on a silicon slide and subsequently dried in a vacuum oven before SEM measurements.

XRD of the AgNPs

$\mathrm{X}$-ray diffraction experiments were carried out in a Bruker diffract meter, D8 Advance DaVinci model with $\mathrm{Cu} \mathrm{K \alpha}$ radiation $(40 \mathrm{kV}, 40 \mathrm{~mA})$. The colloidal solutions were mixed with amorphous silica microbeads followed by centrifugation. The precipitate was dried out under vacuum. The resulting powder was spread out on a silicon antireflection slide.

\section{Surface-Enhanced Raman Scattering (SERS) Spectrum of R6G}

Raman spectra were measured using a Bruker Raman spectrometer; model Senterra with laser excitation at $633 \mathrm{~nm}$, and laser power at $10 \mathrm{~mW}$. Spectral data were collected using a 50x microscope objective ( $\mathrm{NA}=0.51)$ with $30 \mathrm{~s}$ integration time. The SERS samples were prepared by mixing $360 \mu \mathrm{L}$ of colloidal solution with $40 \mu \mathrm{L}$ of aqueous solutions of the probe molecule, resulting in a final $\mathrm{R} 6 \mathrm{G}$ concentration of $1.0 \times 10^{-5} \mathrm{~mol} \mathrm{~L}^{-1}$.

\subsection{Antifungal activity of Ag NPs}

Fungal species 
183

184

185

186

187

188

189

190

191

192

193

194

195

196

197

198

199

200

201

202

203

204

205

206

207

208

209

210

211

212

213

214

215

216

217

218

219

220

221

Microbiological analyses were performed using standard C. albicans, American Type Culture Collection (ATCC) 10231; C. glabrata (Taniwaki, M.H.), Collection of Tropical Cultures (CCT) 0728; C. krusei, (FTI) CCT 1517; C. guilliermondii (CCT), 1890 from the Foundation André Tosello (Campinas, São Paulo, Brazil).

\section{Antifungal activity}

MIC and MFC values were established according to the protocol M27-A2 of the Clinical and Laboratory Standards Institute (CLSI) (CLSI, 2002). Briefly, fungal suspensions were obtained from respective lineages using sterile saline solution [0.9\% (v/v)] after $48 \mathrm{~h}$ of growth at $35 \pm 2{ }^{\circ} \mathrm{C}$. Densities of suspensions were adjusted to $89 \%-90 \%$ transmittance in a spectrophotometer (Libra S12, Biochrom, Denmark) at a fixed wavelength of $530 \mathrm{~nm}$. Samples were then diluted in buffered Roswell Park Memorial Institute (RPMI) 1640 medium (Sigma Aldrich Chemistry, USA) with 3(N-morpholino) propanesulfonic (MOPS) (JTBaker, Germany) to obtain 5-25 $\times 10^{2} \mathrm{CFU}$ and $\mathrm{pH}$ was adjusted to $7.0 \pm 0.1$ using 0.5 -M sodium hydroxide.

Assays were performed in triplicate and plant extract and AgNPs were diluted to 9.7-5,000 $\mu \mathrm{g} \mathrm{mL} \mathrm{m}^{-1}$ in RPMI-1640 medium containing MOPS buffer and $2 \mu \mathrm{L}$ of $70 \%(\mathrm{v} / \mathrm{v})$ ethanol solution. Sterile polypropylene microplates with 96 wells and level depths were purchased from Sarstedt (Germany), and 100- $\mu \mathrm{L}$ aliquots of respective dilutions of vegetable extract and AgNPs were added with $100 \mu \mathrm{L}$ aliquots of standardized fungal suspensions. Control wells contained $100 \mu \mathrm{L}$ of the same inoculated culture medium containing $2 \mu \mathrm{L}$ of $70 \%$ ethanol and $98 \mu \mathrm{L}$ of RPMI 1640 medium containing MOPS. The negative control contained $200 \mu \mathrm{L}$ of medium. Amphotericin B (Cristália, Brazil) and nystatin (Cavalieri, Brazil) were used as reference drugs at $0.0313-16.0 \mu \mathrm{g} \mathrm{mL}^{-1}$.

After inoculation, microplates were incubated at $35 \pm 2{ }^{\circ} \mathrm{C}$ for $48 \mathrm{~h}$, and MIC values were established as the lowest concentration in which no fungal growth was observed. MFC values were determined using the microdilution method. Briefly, $10-\mu \mathrm{L}$ aliquots were withdrawn from wells in which no growth was observed in the MIC procedure, were transferred to new wells containing $1 \mathrm{~mL}$ of Sabouraud dextrose broth (SDB), and were incubated at $35 \pm 2{ }^{\circ} \mathrm{C}$ for $48 \mathrm{~h}$. Subsequently, concentrations with no fungal growth were classified as MFC values.

\subsection{Cytotoxicity}

\section{Evaluation of cell viability using MTT assays}

Cell viability of murine L929 fibroblasts cells (Federal University of Minas Gerais) was evaluated after culture in DMEM (Nutricell, Brazil) supplemented with $10 \%$ fetal bovine serum (SFB) (Invitrogen, USA), 100-U mL-1 penicillin, 100-U mL-1 streptomycin, and 10-mM 4-(2HidroxiEthil)-1-PiperazinEthanolSulfonic buffer (HEPES) (Mosmann, 1983). Cells were cultured in sterile 96-well plates with level depths (Sarstedt, Germany) at a density of $5 \times 10^{3}$ cells per well and were then incubated in an incubator at $37 \pm 2^{\circ} \mathrm{C}$ in an atmosphere containing $5 \%$ 
$222 \mathrm{CO}_{2}$ for $48 \mathrm{~h}$. Subsequently, culture media were replaced with sample solutions at concentrations 223 of $7.81-1,000 \mu \mathrm{g} \mathrm{mL}^{-1}$. Plates were then incubated at $37 \pm 2^{\circ} \mathrm{C}$ in an atmosphere containing $5 \%$ $\mathrm{CO}_{2}$ for $48 \mathrm{~h}$. Controls were not inoculated and contained $2 \mu \mathrm{L}$ of $70 \%(\mathrm{v} / \mathrm{v})$ ethanol solution. After $48 \mathrm{~h}$, culture media were removed and $100-\mu \mathrm{L}$ aliquots of $10 \%$ [3-(4,5-dimethylthiazol-2yl)-2,5-diphenyltetrazolium bromide] (MTT; $5 \mathrm{mg} \mathrm{mL}^{-1}$ ) in DMEM were added to all wells. Plates were immediately incubated at $37 \pm 2^{\circ} \mathrm{C}$ in an atmosphere containing $5 \% \mathrm{CO}_{2}$ for $3 \mathrm{~h}$. Finally, the resulting formazan crystals were dissolved in DMSO and absorbance was evaluated using a spectrophotometer (SpectraMax 190, Molecular Devices, Sunnyvale, CA, USA) at 540 nm (Twentyman \& Luscombe, 1987).

\title{
Statistical analysis
}

\section{Results and Discussion \\ 3. Results and Discussion}

Data are expressed as means \pm standard errors of the mean and are representative of 5 replicates. Differences were identified using analyses of variance (ANOVA) followed by Bonferroni's test (Graphpad Prism versão 6 e IBM SPSS Statistics 21) and were considered significant when $p<0.05$.

(1)

\begin{abstract}
The results show that this process allows for the rapid synthesis of AgNPs from the $C$. ferrea seed extract, which acts as a reducing and stabilizing agent for silver ions. AgNPs can be synthesized in minutes and up to $24 \mathrm{~h}$ in the presence of ammonia, which favors the formation of a soluble silver complex (Chandran et al., 2006; Stephen et al., 2013).

In this study, AgNPs were synthesized in a few minutes and immediately followed by UVVis absorption spectroscopy and SEM. Figure 1 shows a UV-Vis absorption spectrum, after 24h, in the region between 200 and $600 \mathrm{~nm}$ for a $\mathrm{AgNO}_{3}: \mathrm{NaOH}$ solution (990:0.5 v/v) (black line), $C$. ferrea extract (red line), and AgNPs (blue line). The maximum absorption in the spectrum (blue line), centered at $423 \mathrm{~nm}$, indicates the formation of AgNPs (the wavelength at $423 \mathrm{~nm}$ is a typical value) (Seyed \& Sattar, 2009).
\end{abstract}

\section{\{Insert figure 1\}}

Figure 2 exhibits the SERS spectrum of R6G in aqueous $10 \mathrm{mmol} \mathrm{L}^{-1}$ solution and dispersed in a colloidal suspension of AgNPs at $1.0 \times 10^{-5} \mathrm{~mol} \mathrm{~L}^{-1}$ of the dye. R6G presents a very strong absorption band at $527 \mathrm{~nm}$; therefore, to avoid the resonance Raman and fluorescence associated with R6G, exciting radiation at $633 \mathrm{~nm}$ was used. Both Raman and SERS spectra show the same spectral profile, containing similar vibrational features characteristic of the dye (Hildebrand \& Stockburger, 1984) but with different relative intensities. 
The adsorption of R6G on the silver surface enhances the intensity of some bands with a low cross section in the spectrum of the pure molecule. The change in relative intensity in SERS (Zhou et al., 2012) is a consequence of both chemical interaction of the dye with the surface and localized surface plasmon resonance conditions, given by the local electric field enhancement near the metal surfaces because of the oscillating surface dipole (Fan, Andrade, \& Brolo, 2011). To verify the observed SERS enhancement on the AgNPs synthesized in the present work, we used the simplest equation for the SERS enhancement factor (Le ru et al., 2007), $\mathrm{EF}_{\mathrm{SERS}}=$ $\left(I_{\text {SERS }} / I_{\text {Raman }}\right) \times\left(C_{\text {Raman }} / C_{\text {SERS }}\right)$, where $I_{\text {SERS }}$ is the measured intensity for a given band, $I_{\text {Raman }}$ is the Raman intensity measured for the same band, $C_{\text {Raman }}$ is the concentration of R6G in the solution used for acquiring the Raman spectrum, and $C_{\mathrm{SERS}}$ is the concentration of R6G in the colloidal suspension. The band at $1510 \mathrm{~cm}^{-1}$ was chosen for the calculation. The synthesized AgNPs presented an $\mathrm{EF}_{\mathrm{SERS}}$ of approximately $7.2 \times 10^{2}$ times in the experimental conditions used, making AgNPs an interesting SERS substrate.

\section{\{Insert figure 2\}}

Figure 3 shows a SEM image and a histogram of the AgNP sizes obtained from the $C$. ferrea extract, always considering the longest axis for the measurement. SEM (Fig. 3a) confirmed the formation of AgNPs, and the predominant morphology is a spheroidal shape with a wide-size distribution. Furthermore, agglomerates are formed possibly by the drying process. In the histogram in Fig. $3 b$, the size distribution of the AgNPs shows a mean diameter approximately $30-50 \mathrm{~nm}$. The histogram was obtained by counting approximately 140 particles in different regions. The morphology observed by SEM is consistent with the UV-Vis spectroscopy results presented in Fig. 1.

\section{\{Insert figure 3\}}

Figure 4 shows the XRD analysis of AgNPs. The diffractogram illustrates diffraction peaks at $2 \theta=38.15^{\circ}, 44.25^{\circ}, 64.47^{\circ}, 77.38^{\circ}$, and $81.64^{\circ}$. The well-defined peaks indicate high crystallinity of the AgNPs, corresponding to a cubic unitary cell for nanocrystals. The UV-Vis spectroscopy, SERS, SEM, and XRD results confirm the formation of AgNPs when using the $C$. ferrea extract as a reducing and stabilizing agent.

\section{\{Insert figure 4\}}

In relation to the antifungal activity the AgNPs were tested in the range of 9.7-5,000 $\mu \mathrm{g}$ $\mathrm{mL}^{-1}$ (Table 1). It was observed antifungal action against $C$. albicans (MIC $=312.5 \mu \mathrm{g} \mathrm{mL}^{-1}$ ), $C$. 
glabrata $\left(\mathrm{MIC}=1,250 \mu \mathrm{g} \mathrm{mL}^{-1}\right)$, C. kruzei $\left(\mathrm{MIC}=312.5 \mu \mathrm{g} \mathrm{mL}^{-1}\right)$ and C. guilliermondii $(\mathrm{MIC}=$ $\left.156.25 \mu \mathrm{g} \mathrm{mL}^{-1}\right)$. Both $C$. ferrea extract and AgNPs were active under experimental conditions.

\section{$\{$ Insert table 1\}}

The biocidal activity of AgNPs depends on their size, shape, surface coatings (Wei et al., 2010; Zhang et al., 2016), and ultrafine structure (Harekrishna et al., 2009). In a study by Esteban-Tejeda et al. (2009), the synthesized AgNPs $(20 \mathrm{~nm})$ showed potent antifungal activity against clinical isolates and Candida ATCC standard strains in concentrations of $1-7 \mu \mathrm{g} \mathrm{mL}^{-1}$.

Prasad et al. (2011) and Otunola et al. (2017) used plant species for the synthesis of AgNPs and showed strong antimicrobial activity on pathogenic microorganisms, including Candida tropicalis, Candida krusei, and Gram-positive and Gram-negative bacteria. The synthesized AgNPs were spherical and between 3-22 $\mathrm{nm}$ and $57 \mathrm{~nm}$ in size.

Plant species have shown great potential in the accumulation of heavy metals and as bioreducing agents (Iravani et al, 2014) in addition to maintaining the antimicrobial activity of silver (Alsahi et al, 2016). This action depends on the $\mathrm{pH}$, reaction temperature, and the nature and concentration of the extract (Mittal et al., 2014).

Although the intracellular pathways involved for these biological effects still remain largely unclear, some authors highlight the presence of secondary metabolites, usually flavonoids, tannins, and polyphenol compounds, as the cause (Bittencourt \& Heinzmann, 2003; Carlson et al., 2008; Mittal et al., 2014; Frasson, Alsahi et al, 2016; Fatimah, 2016).

Besides anthraquinones, alkaloids, depsides, depsidones, lactones, saponins, sugars, sesquiterpenes and triterpenes found in species of $C$. ferrea (Souza et al.; 2006; Sampaio et al., 2009). These secondary metabolites may explain the positive action of the AgNPs reduced by the C. ferrea extract on most strains of Candida studied here: AgNPs effectively inhibited the growth of tested yeasts at concentrations below their cytotoxic threshold against the murine fibroblasts cells tested. The C. ferrea is an economical and ecological important specie in Brazil. NMR study revealed a galactomannan with a 2.65 mannose/galactose ratio was main seed polysaccharide of this plant species (Gallão et al., 2013). Further, the galactomannans, extracted from the endosperm of leguminous seeds, and responsible to perform functions of energy reservation and hydration. They have special properties such as high molar mass, water solubility and non-ionic character. A polysaccharide chain composed of at least 85 to $95 \%$ mannose units will provide intermolecular interactions like hydrogen bonds between cis hydroxyls of mannose, leading to formation of insoluble aggregates. In what concerns non-food industries, galactomannans are used as thickeners and stabilizers in pharmaceutical formulations, such as creams and lotions for cosmetic fields. In addition, these polysaccharides have been applied as matrix in the controlled release of drugs (Albuquerque et al., 2016). 
From an ethanol extract of Caesalpinia ferrea four phenolic compounds were isolated and identified by spectraldata: organic acid 1 and ester 2 (from green beans), biflavonoid 3 and phytoalexin 4 (from stem). Additionally, from this same extract, other constituents (two triterpenes, two steroids, two acid and fatty alcohol) were detected by gas chromatography and characterized by NMR. This plant species is well investigated under the point of view of biological activities, evidencing its therapeutic potential (Magalhães et al., 2014).

The study of Sampaio et al. (2009) showed that the extract of C. ferrea Martius has a good inhibitory effect upon oral microorganism since MIC values ranged between 250 and 1000 $\mu \mathrm{g} \mathrm{mL} \mathrm{m}^{-1}$ which corroborates with the results os this study.

Extracts and polysaccharide fractions of $C$. ferrea pods exhibit potent anti-inflammatory activity via negative modulation of histamine, serotonin, bradykinin, $\mathrm{PGE}_{2}$ and $\mathrm{NO}$ could be interfering not only in the vascular, but also in cellular inflammatory events being well tolerated by animals (Pereira et al., 2012).

C. ferrea has several biological activities (Bariani et al., 2012). With respect to cytotoxicity in murine $\mathrm{L} 929$ fibroblast cells exposed for $48 \mathrm{~h}$ to $C$. ferrea extract and coated AgNP, the results demonstrated a dose-dependent increase in AgNP concentration, causing significant cell death for the C.ferrea extract only at the highest concentration of $1000 \mu \mathrm{g} \mathrm{mL}^{-1}$.

Hussain et al. (2005) and Alsalhi et al. (2016) evaluated the in vitro toxicity of AgNPs of different sizes $(15 \mathrm{~nm}$ or $100 \mathrm{~nm})$ at different concentrations. The mitochondrial function decreased significantly in cells treated with higher doses of AgNPs, and the cells showed cell retraction and an irregular shape. In this study, at lower concentrations of AgNPs, greater cell viability is observed $\left(3.5,7.0\right.$, and $\left.15 \mu \mathrm{g} \mathrm{mL}^{-1}=96.43 \% \pm 0.43\right)$. Both the $C$. ferrea extract and AgNPs presented high cell viability in a percentage range of $82.32 \%-102.71 \%$ and $67.13 \%-$ $96.43 \%$, respectively, in concentrations ranging from 3.5 to $1000 \mu \mathrm{g} \mathrm{mL}^{-1}$ (Fig. 5).

\section{$\{$ Insert figure 5\}}

Factors crucial for determining cytotoxicity include size, distribution, morphology, and composition of AgNPs; coatings, agglomeration, and rate of dissolution; reactivity of the particles in solution; and the type of reduction agents used for the synthesis of AgNPs. Of these, particle size is critical because of its influence on the bioavailability, biodegradability, and in vivo toxicity of AgNPs, a factor that still needs to be better understood (Wei et al., 2010; Marcato et al., 2012; Shinde et al., 2012; Zhang et al., 2016 ).

Jeeva et al. (2014) showed that the morphology of the AgNPs synthesized using Caesalpinia leaf extracts was found as a triangle shape with a diameter range of $40 \mathrm{~nm}$ to $52 \mathrm{~nm}$, whereas in the extracts of centrifuged leaves three triangle, hexagonal and spherical forms were observed with one average size between $78 \mathrm{~nm}$ and $98 \mathrm{~nm}$. In addition, the synthesized AgNPs showed potential antimicrobial activity against human pathogens. 
Small AgNPs have a large surface area, a greater potential to invade cells, and, therefore, a greater cytotoxic potential (Wei et al., 2010, Nogueira, Paino \& Zucolotto, 2013; Zhang et al., 2016). In a study by Wei et al. (2010), AgNPs (50-100 nm) induced apoptosis, increased DNA fragmentation, and induced structural mitochondrial and membrane damage in L929 cells, which resulted in cell death. These effects are because of the presence of silver ions, which deactivate cellular enzymes and damage the cell membrane of fungi. The main mechanism of action appears to be associated with increased levels of oxygen-reactive species (Hussain et al., 2005; Shinde, 2012; Nogueira, Paino \& Zucolotto, 2013; Monalisha, Swati \& Nabin, 2014; Alsahi et al., 2016).

In this study, the presence of silver ions in AgNP coated with C. ferrea (30-50 nm) appeared to have no effect on L929 cells.

Green synthesis with $C$. ferrea provides advancement over chemical and physical method as it is cost effective, environment friendly, easily scaled up for large scale synthesis.

This study demonstrated that $C$. ferrea can be used as a bioreducing agent for the biosynthesis of AgNPs of adequate size, shape, and stability. These AgNPs show considerable antifungal activity on Candida albicans, Candida kruzei, and Candida guilliermondii and high cell viability in murine L929 fibroblasts cells.

Our results should provide a valuable reference for the future treatment of fungal diseases. The ability to biosynthesize AgNPs using $C$. ferrea is highly promising as a simple and reproducible process of sustainable green synthesis. Nevertheless, additional in vivo studies should be undertaken to better understand the efficacy of AgNPs before developing them for clinical applications.

\section{Conclusions}

This study demonstrated that $C$. ferrea can be used for AgNP biosynthesis. The biosynthesized AgNPs were adequate for size, shape and stability, obtained considerable antifungal activity on $C$. albicans, $C$. kruzei and $C$. guilliermondii. In adittion, hight cell viability on murine L929 fibroblasts cells. Therefore, the ability to biosynthesize AgNPs using C. ferrea is highly promising as a simple and reproducible process of sustainable green synthesis.

\section{References}

1. Albuquerque, P.B.S.; Coelho, L.C .B. B.; Correia, M.T. S.; Teixeira, J.A.; Carneiro-daCunha, M.G. Biotechnological Applications of Galactomannan Matrices: Emphasis on Immobilization of Biomolecules. Advances in Research. 2016, 6: 1-17.Article no.AIR.23435 ISSN: 2348-0394, NLM ID: 101666096 SCIENCEDOMAIN international www.sciencedomain.org

2. Alsahi, M.S; Devanesan, S.; Alfurayd, A.; Vishnubalaji, R..; Munusamy, A.; Murugan, K.; Nicoletti, M.; Benelli, G. Green synthesis of silver nanoparticles using Pimpinella anisum 
seeds: antimicrobial activity and cytotoxicity on human neonatal skin stromal cells and colon cancer cells. International J Nanomedic, 2016, 11, 4439-4449.

3. Araújo, A.A.; Soares, L.A.; Ferreira, M.R.; Souza-Neto, M.A.; Silva, G.R.; Araújo, R.F., Jr. Quantification of polyphenols and evaluation of antimicrobial, analgesic and antiinflammatory activies of aqueous and acetone-water extracts of Libidibia ferrea, Parapitadenia rigida and Psidium guajava. Journal of Ethnopharmacology 2014, 156, 8896. 10.1016/j.jep.2014.07.031. www.elsevier.com/locate/jep.

4. Bariani, A.; Gonçalves, J.F.; Chevreuil, L.R.; Cavallazzi, J.R.; Souza, L.A.; Bentes, J.L.; Pando, S. C. Partial purification of trypsin inhibitors from Caesalpinia ferrea and Swartzia polyphylla and effect of protein extracts on phytopathogenic fungi Summa Phytopathologica 2012, 38, 131-138. 10.1590/S0100-54052012000200004. http://www.scielo.br/pdf/sp//v38n2/04.pdf.

5. Carlson, C.; Hussain, S.M.; Schrand, A.M.; Braydich, L.K.; Hess, K.L.; Jones, R.L.; Schlager, J.J. Unique cellular interaction of silver nanoparticles: size-dependent generation of reactive oxygen species. J Phys Chem B. 2008, 112:13608-13619.

6. Castro-Longoria, E.; Vilchis-Nestor, A.R.; Avalos-Borja, M.. Biosynthesis of silver, gold and bimetallic nanoparticles using the filamentous fungus Neuropora crassa.Colloids Surf. B. Biointerfaces. 2011, 83, 42-48.

7. Cavalheiro, M.G.; Farias, D.F.; Fernandes, G.S.; Nunes, E.P.; Cavalcanti, F.S.; Vasconcelos, I.M.; Melo, V.M.; Carvalho, A.F.. Biological and enzymatic activities of the aqueous extract of Caesalpinia ferrea Mart., Leguminosae. Brazilian Journal of Pharmacognosy 2009, 19, 586-591. 10.1590/S0102-695X2009000400014. htpp// www.scielo.br/pdf/rbfar/ v19n2b/a14v192b.pdf.

8. Chandran, S.P. .; Chaudhary, M., Pasricha, R., Ahmad, A. and Sastry, M. Synthesis of Gold Nanotriangles and Silver Nanoparticles Using Aloe vera Plant Extract. Biotechnol Progress, 2006, 22: 577-583. doi: 10.1021/bp0501423.

9. CLSI. Clinical and Laboratory Standards Institute. (2002). Reference method for broth dilution tests for the determination of sensitivity to antifungal therapy of filamentous fungi: approved standard, 22, 16. M38-A.

10. Das, B.; Khan, M. I.; Jayabalan, R.; Behera, S. K.; Yun, S. I.; Tripathy, S. K.; Mishra, A., Understanding the Antifungal Mechanism of Ag@ZnO Core-shell Nanocomposites against Candida krusei. Sci Rep, 2016, 6. 6-36403.Doi: 10.1038/srep36403.

11. Dúran, N.; Conti, R. D.; Alves, O. L.; Costa, F. T. M.; Brocchi, M. Potential use of silver nanoparticles on pathogenic bacteria, their toxicity and possible mechanisms of action. $J$. Braz. Chem. Soc. 2010, 21 (6), 949-959.

12. Dutra, R.C.; Campos, M.M.; Santos, A.R.; Calixto, J.B. Medicinal plants in Brazil: pharmacological studies, drug, discovery, challenges and perspectives. Pharmacol Res 2016, 112, 4-29. 10.1016/j.phrs.2016.01.021. htpp:// dx.doi.org.phrs.2016.01,021.

13. Esteban-Tejeda, L.; Malpartida, F.; Esteban-Cubillo, A.; Pecharroman, C.; Moya, J.S. The antibacterial and antifungal activity of a soda-lime glass containing silver nanoparticles. Nanotechnology. 2009, 20:085103. doi: 10.1088/0957-4484/20/8/085103.

14. Fan, M.K.; Andrade, G.F.S.; Brolo, A.G.A. A review on the fabrication of substrates for surface enhanced Raman spectroscopy and their applications in analytical chemistry. Analytica Chimica Acta. 2011, 693: 7-25. ISSN 0003-2670. Available at: $<<$ Go to ISI>://WOS:000290886800002. 
15. Fatimah, I. Green synthesis of silver nanoparticles using extract of Parkia speciosa Hassk pods assisted by microwave irradiation. Journal of Advanced Research 2016, 7: 961969. https://doi.org/10.1016/j.jare.2016.10.002.

16. Frasson, A.P.Z.; Bittencourt, C.F.; Heinzmann, B.M. Caracterização físico-química e biológica do caule de Caesalpinia ferrea Mart. Rev Bras Farmacog 2003, 13:35-39.

17. Gallão, M.I.; Normando, L.O.; Vieira, I.G.P.; Mendes, F.N.P.; Ricardo, N.M.P.S.; Brito, E.S. Morphological, chemical and rheological properties of the main seed polysaccharide from Caesalpinia ferrea Mart. Industrial Crops and Products. 2013, 47: 58-62. https://doi.org/10.1016/j.indcrop.2013.02.035.

18. Geronikaki, A.; Fesatidou, M.; Kartsev, V.; Macaev, F. Syntehsis and biological evaluation of potent antifungal agents. Current topics in Medicinak Chemistry, 2013, 21(2), 312-321.

19. Harekrishna, D.K.B.; Gobinda, P.S.; Priyanka, S.; Santanu, P.; Ajay, M. Green synthesis of silver nanoparticles using seed extract of Jatropha curcas. Colloids Surf A Physicochem Eng Asp. 2009, 348: 212-216.

20. Hildebrand, P.; Stockburger, M. Surface-enhanced resonance raman-spectroscopy of rhodamine-6g adsorbed on colloidal silver. Journal of Physical Chemistry, 1984, 88: 59355944. ISSN 0022-3654. available at: <<Go to ISI >://WOS:A1984TU20800038 >.

21. Hussain, S.; Hess, K.; Gearhart, J.; Geiss, K.; Schlager, J.; Toxicol. In vitro 2005, 19, 975.

22. Iravani, S. Green synthesis of metal anoparticles using plants. Green Chemistry, 2011, 13 (10), 2638-2650.

23. Iravani, S.; Korbekandi, H.; Mirmohammadi, S.V.; Zolfaghari, B. Synthesis of silver nanoparticles: chemical, physical and biological methods. Research in Pharmaceutical Sciences. 2014, 9:385-406.

24. Jacometo, W.; Fernandes, G.; Fernandes, R.; Amaral, J.; ER, E. C.; Barbosa, D. O-112 Glicerofosfato de cálcio impregnado com nanopartículas de prata: caracterização e eficácia antimicrobiana. 2015, 4.

25. Jeeva, K.; Thiyagarajan, M.; Elangovan, V.; Geetha, N.; Venkatachalan, P. Caesalpinia coriaria leaf extracts mediated biosynthesis of metallic silver nanoparticles and their antibacterial activity against clinically isolated pathogens. Industrial Crops and Products, 2014, 52, 714-72.

26. Kobayashi, Y.T.; Almeida, V;T.; Bandeira, T.; Alcântara, B.N.; Silva, A.S.; Barbosa, W.L.R.; Silva, P.B.; Almeida, M.B.; Monteiro, V. Phytochemical evaluation and healing potential of the ethanolic extract of the fruits of Jucá (Libidinia ferrea) in wistar rats. Braz. J. Vet. Res. Anim. 2015, 52, 34-40. http://www.revistas.usp.br/bjvras/ article/view/61477.

27. Kubyshkin, A.; Chegodar, D.; Katsev, A.; Petrosyan, A.; Krivorutchenko, Y.; Postnikova, O. Antimicrobial effects of silver nanoparticles stabilized in solution by sodium alginate. Biochem Mol Biol J. 2016, 2 (2). doi:10.21767/2471-8084.100022.

28. Lakum, H.P.; Shah, D.R.; Chikhalia, K.H. Novels-triaziny Schiff base/chalcone congeners: ration, synthesis, antimicrobial and anti-TB evaluation. Int. Lett. Chem., Phys. Astron. 2014, 19(1): 56-73.

29. Le ru, E.C.; Blackie, E.; Meyer, M and Etchegoin, P.G.. Surface enhanced Raman scattering enhancement factors: a comprehensive study. Journal of Physical Chemistry C. 2007, 111: 13794-13803. ISSN 1932-7447. Available at: $<<$ Go to ISI $>$ ://WOS:000249501800024.

30. Magalhães, I.L.; Lima Pinto, F.C.; Braz Filho, R.B.; Ferreira, D.A.; Lemos, T.L.G.; Monte, F.J.Q. Chemical Constituents from Caesalpinia ferrea: Identification and $1 \mathrm{H}$ and $13 \mathrm{C}$ Resonance Assignment. American Journal of Analytical Chemistry, 2014, 5: 688-694. 
502

Published Online July 2014 in SciRes. http://www.scirp.org/journal/ajac. http://dx.doi.org/10.4236/ajac.2014.510077.

31. Mallmann, E.J.J.; Cunha, F.A.; Castro, N.M.F.; Machado, A.M.; Menezes, E.A.; Fechine, P.B.A. Antifungal activity of silver nanoparticles obtained by green synthesis. Rev. Inst. Med. Trop. 2015, 57 (2), 165-167. doi: 10.1590/s0036-46652015000200011.

32. Marcato, P.D.; Duran, M.; Huber, S.; Rai, M.; Melo, P.S.; Alves, O.L. and Duran, N. Biogenic silver nanoparticles and its antifungal activity as a new topical transungual drug delivery. J Nano Res, 2012, 20, 99-107.

33. Mittal, A.K.; Bhaumik, J.; Uttam, S.K.; Banerjee, C. Biosynthesis of silver nanoparticles: Elucidation of prospective mechanism and therapeutic potential. Journal of Colloid and Interface Science 2014, 1: 39-47.

34. Monalisha, R.; Swati, S.P.; Nabin, K.D. Synthesis of silver nano particles from plant extract and its application in cancer treatment: a review. Int J Plant Animal Environ Sci. 2014, 4:137-145.

35. Morais-Braga, M.; Sales, D.; Carneiro, J.; Machado, A.; Santos, A.; Freitas, A. \& Martins, G.. Psidium guajava L. and Psidium brownianum Mart ex DC.: Chemical composition and anti-Candida effect in association with fluconazole. Microbial Pathogenesis. 2016, 95: 200207. 10.1016/j.micpath.2016.04.013. http://dx.doi.org/10.1016/j.micpath.2016.04.013.

36. Mosmann, T. Rapid Colorimetric assay for cellular growth and survival: application to proliferation and cytotoxicity assays. Journal of Immunological Methods, 1983, 65: 55-63. 10.1016/0022-1759(83)90303-4. htpp://dx.doi.org/10.1016/0022-1759 (83)90303-4.

37. Nogueira, P.F.M;. Paino, I.M.M.; Zucolotto, V. Nanosilver: Properties, applications and impacts on health and invironment. Vigilância Sanitária em Debate 2013, 1: 57-68. Doi: 10.3395/vd.v1i4.88pt.

38. Oliveira, I.V. P.M.; Dias, R.V. C; Calado, E.B.; Lucena, R.; Costa, A.L.; Sakamoto, S.M.; Pimentel, M.M.L. Evaluation macroscopically scar of the string bean and the hull of the Caesalpinia ferrea (tul.) Martius ("jucá") on the cutaneous wounds of the asinine (equus asinus). Acta Veterinária Brasílica 2014, 8, 129-135.

39. Otunola, G.A.; Afolayan, A.J.; Ajayi, E.O.; Odeyemi, S.W. Characterization, antibacterial and antioxidant properties of silver nanoparticles synthesized from aqueous extraxcts of Allium sativum, Zingiber officinale and Caspsicum frutescens. Phcog Mag [serial online] 2017, 24:13. Suppl S2:201-8. Available from:htpp://www.phcog.com/text.asp?2017/13/50/201/210181.

40. Prasad, T.N.; Elumalai, E. Biofabrication of Ag nanoparticles using Moringa oleifera leaf extract and their antimicrobial activity. Asian Pac j Trop Biomed, 2011: 439-442.

41. Pereira, L.P.; Silva, R.O.; Bringel, P.H.S.F.; Silva, K.E.S.; Assreuy, A.M.S.; Pereira, M.G. Polysaccharide fractions of Caesalpinia ferrea pods: Potential anti-inflammatory usage. Journal of Ethnopharmacology, 2012, 139:642-648.

42. Sampaio, F.C.; Pereira, M.S,V.; Dias, C.S.; Costac, V.C.O.; Conde, N.C.O.; Buzalaf, M.A.R.. In vitro antimicrobial activity of Caesalpinia ferrea Martius fruits against oral pathogens. Journal of Ethnopharmacology 2009, 124:289-294.

43. Seyed, S.M.; Sattar, G. Experimental study on effect of different parameters on size and shape of triangular silver nanoparticles prepared by a simple and rapid method in aqueous solution. Arabian J Chem. 2009, 2:47-53.

44. Shaik, M.R.; Qandeel Ali, Z.J.; Khan, M.; Kuniyil, M.; Assal, M.E.; Alkhathan, H.Z.; AlWarthan, A.; Siddiqui, M.R.H.; Khan, M.; Adil, S.F. Green synthesis and characterization 
of palladium nanoparticles using Origanum vulgare L. extract and their catalytic activity. Molecules 2017, 22, 163; doi:10.3390/molecules22010165. www.mdpi.com/journal/molecules.

45. Shinde, S.K.; Grampurohit, N.D.; Gaikwad, D.D.; Jadhav, S.L.; Gadhave, M.V.; Shelke, P.K. Toxicity induced by nanoparticles. Asian Pac J Trop Dis 2012, 2: 331-334.

46. Silva, F.D.B.; Sales, M.A.G.; Sá, O.R.M.; Santana, G.M.; De Deus, M.S.M.; Castro e Souza, J.M.; Peron, A.P.; Ferreira, P.M.P. Cytotoxic, genotoxic and cytoprotective potential of aqueous extracts of Caesalpinia pyramidalis Tul., Caesalpinia ferrea Mart. and Caesalpinia pulcherrima Sw. R. Bras. Bioci. 2015, 13, 101-109. htpp// www.ufrgs.br/seerbio/ojs/index. $\mathrm{php} / \mathrm{rbb} / \mathrm{article} / \mathrm{view} / 3252$.

47. Song, J.Y.; Kim, B.S. Rapid biological synthesis of silver nanoparticles using plant leaf extracts. Bioprocess Biosyt Eng, 2009, 32: 79. https://doi.org/10.1007/s00449-008-0224-6. Online ISSN1615-7605.

48. Souza, A.B., Souza, L.M.S., Carvalho, J.C.T., Maistro, E.L. No clastogenic activity of Caesalpinia ferrea Mart. (Leguminosae) extract on bone marrow cells of Wistar rats. Genetics and Molecular Biology 2006, 29, 380-383.

49. Stephen, A.; Seethalakshmi, S. Phytochemical Synthesis and Preliminary Characterization of Silver Nanoparticles Using Hesperidin. 2013, Article ID 126564, 6 pages. http://dx.doi.org/10.1155/2013/126564

50. Szweda, P.; Gucwa, K.; Kurzyk, E.; Romanowska, E.; Dzierzanowska-Fangrat, K.; Zielinska Jurek, A.; Kus, P. M.; Milewski, S. Essential Oils, Silver Nanoparticles and Propolis as Alternative agents against Fluconazole Resistant Candida albicans, Candida glabrata and Candida krusei clinical isolates. Indian J Microbiol 2015, 55 (2), 175-83. PMCID: 4363251.doi: 10.1007/s12088-014-0508-2.

51. Twentyman, P.R., Luscombe, M. A study of some variables in a tetrazolium dye (MTT) based assay for cell growth and chemosensitivity. British Journal of Cancer, 1987, 56: 279285.

52. Vasquez-Munoz, R.; Avalos-Borja, M.; Castro-Longoria, E., Ultrastructural Analysis of Candida albicans when Exposed to Silver Nanoparticles. PlosOne, 2014, 9 (10). e108876. doi: 10.1371/journal.pone.0108876.

53. Wei, L.; Lu, J.; Xu, H.; Patel, A.; Chen, Z.; Chen, G. Silver nanoparticles: synthesis, properties, and therapeutic applications. Drug Discov Today. 2015, 20 (5): 595-601. doi:10.1016/j.drudis.2014.11.014.

54. Wei, L.; Tang, J.; Zhang, Z.; Chen, Y.; Zhou, G.; Xi, T. Investigation of the cytotoxicity mechanism of silver nanoparticles in vitro. Biomed Mater. 2010, 5:044103.

55. Xue, B.; He, D.; Gao, S.; Wang, D.; Yokoyama, K.; Wang, L. Biosynthesis of silver nanoparticles by the fungus Arthroderma fulvum and its antifungal activity against genera of Candida, Aspergillus and Fusarium. International Journal of Nanomedicine. 2016, 11, 1899-1906.

56. Yunes, R.A.; Pedrosa, R.C.; Cechinel Filho, V. Drugs and phytotherapics: the need for the development of the herbal and phytopharmaceutical industry in Brazil. Quim. Nova 2001, 24, 147-152.

57. Zhang, X. F.; Liu, Z. G.; Shen, W.; Gurunathan, S. Silver Nanoparticles: Synthesis, Characterization, Properties, Applications, and Therapeutic Approaches. Int $J$ Mol Sci 2016, 17 (9). 
593

594

595

58. Zhou, X.. Liu, G.; Yu, J.; Fan, W. Surface plasmon resonance-mediated photocatalysis by noble metal-based composites under visible light. Journal of Materials Chemistry, 2012, 22: 21337-21354. ISSN 0959-9428. Available at: $<<$ Go to ISI $>$ ://WOS:000309852400001 >. 
Figure 1

UV-vis absorption spectra

Shows UV-vis absorption spectra in the region between 200 and $600 \mathrm{~nm}$ for AgNO3 solution,

C. ferrea extract and AgNPs. 24h pos-exposure.

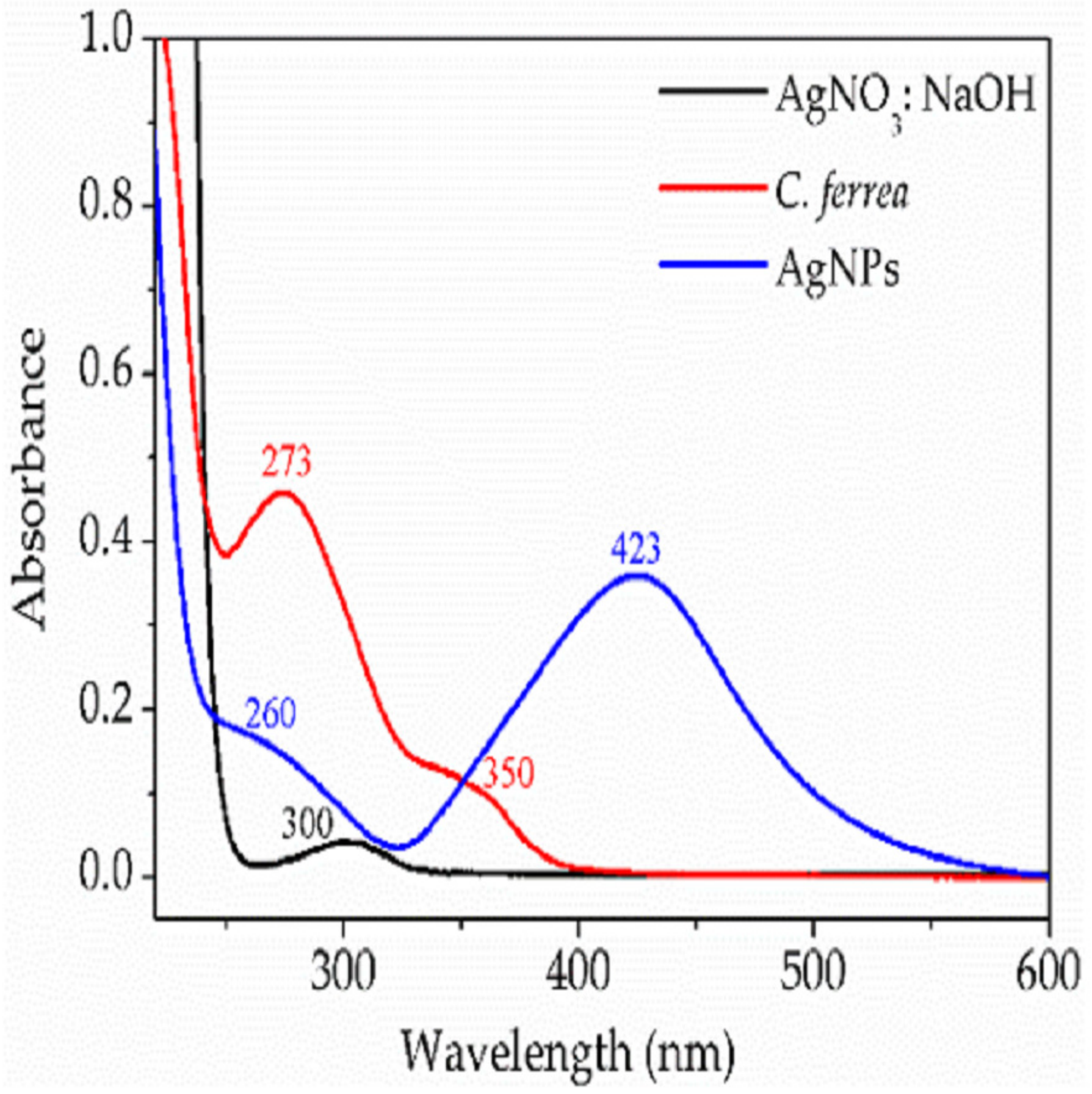


Figure 2

Surface-enhanced Raman scattering (SERS) spectra of rhodamine-6G (R6G)

Raman spectra using laser excitation $633 \mathrm{~nm}$ of samples (a) $10 \mathrm{mmol}^{-1} \mathrm{R} 6 \mathrm{G}$ and (b) silver nanoparticle $1.0 \times 10^{-5} \mathrm{~mol} \mathrm{~L}^{-1} \mathrm{R} 6 \mathrm{G}$.

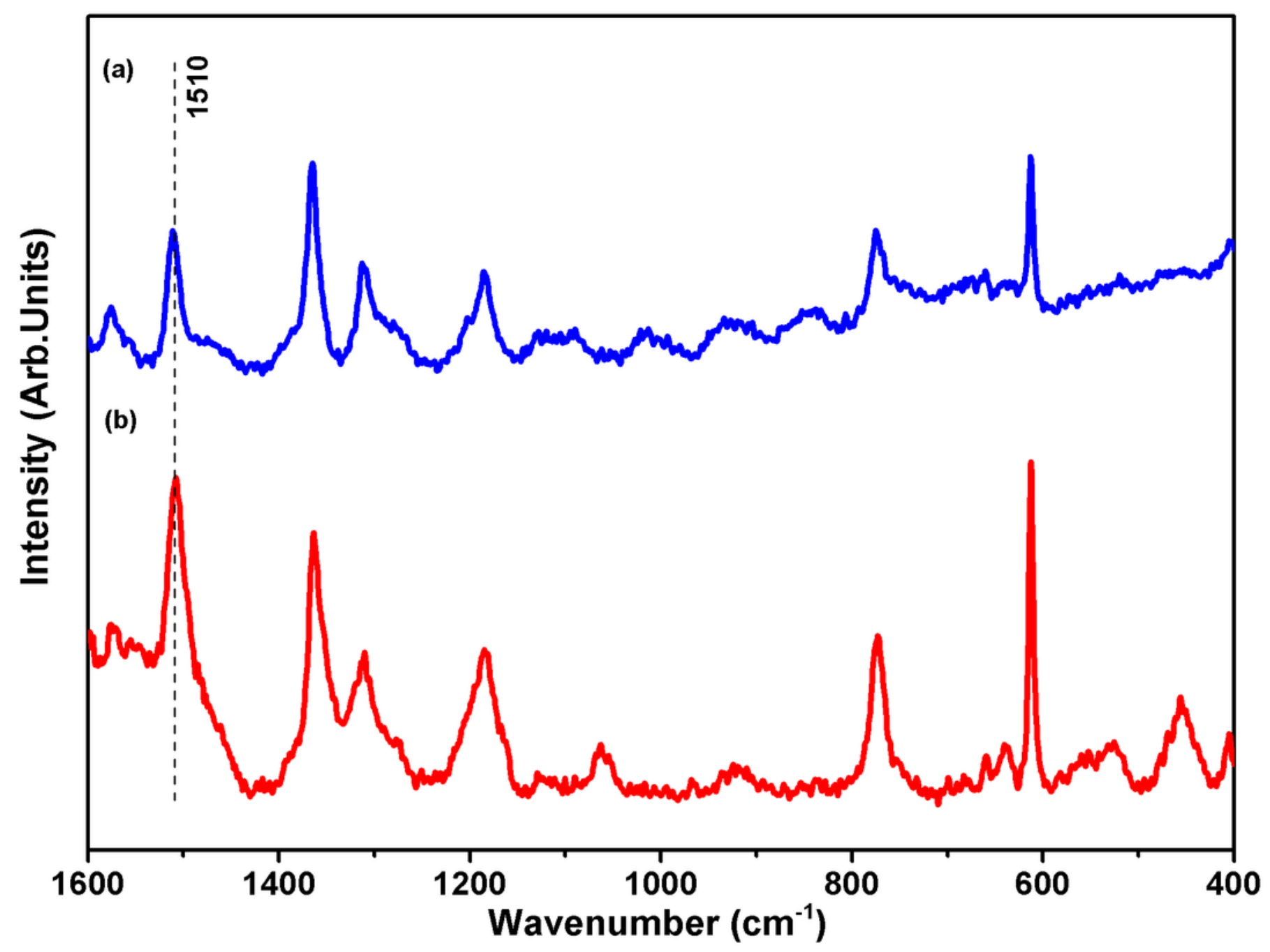


Figure 3

Scanning electron microscopy (SEM)

(A) a representative SEM micrograph of the silver nanoparticles and (B) histogram of the size distribution of silver nanoparticles.

a)

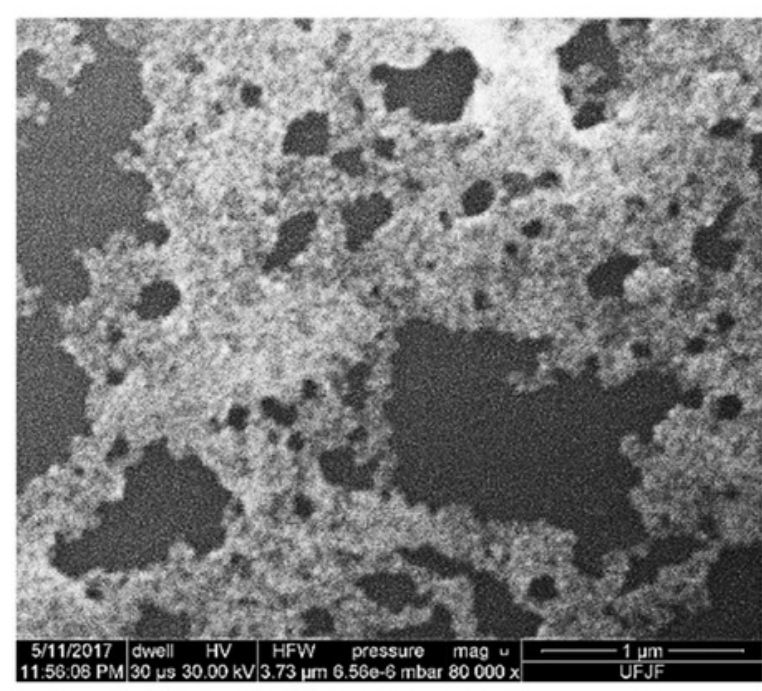

b)

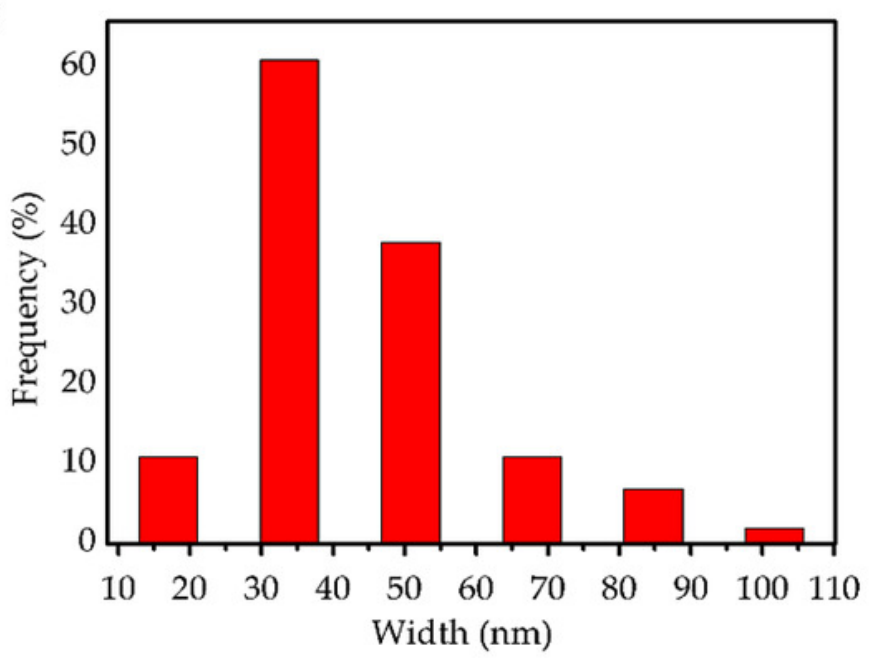


Figure 4

X-ray diffraction (XRD) of the AgNPs

X-ray diffraction related to the diffraction planes of silver nanoparticles.

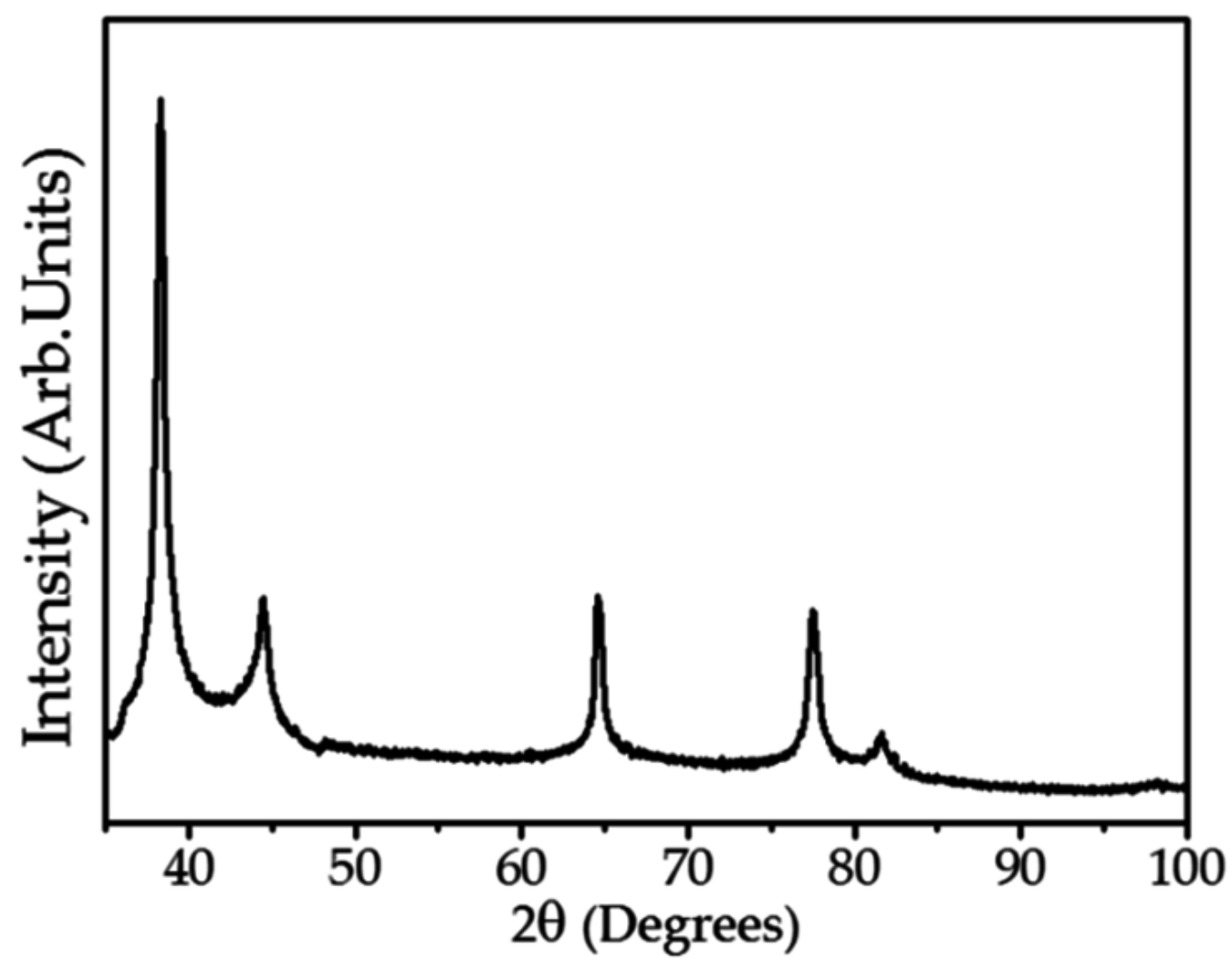


Figure 5

Viability L929 fibroblast cells of the AgNPs

Viability L929 fibroblast cells, 48h pos-exposure to extract of $C$. ferrea (Tul.) Martius (a) and AgNPs (b) in different concentrations. Data are expressed as means \pm standard errors of the mean versus control. Analyses of variance (ANOVA) followed by Bonferroni's test $* p<0.05$.
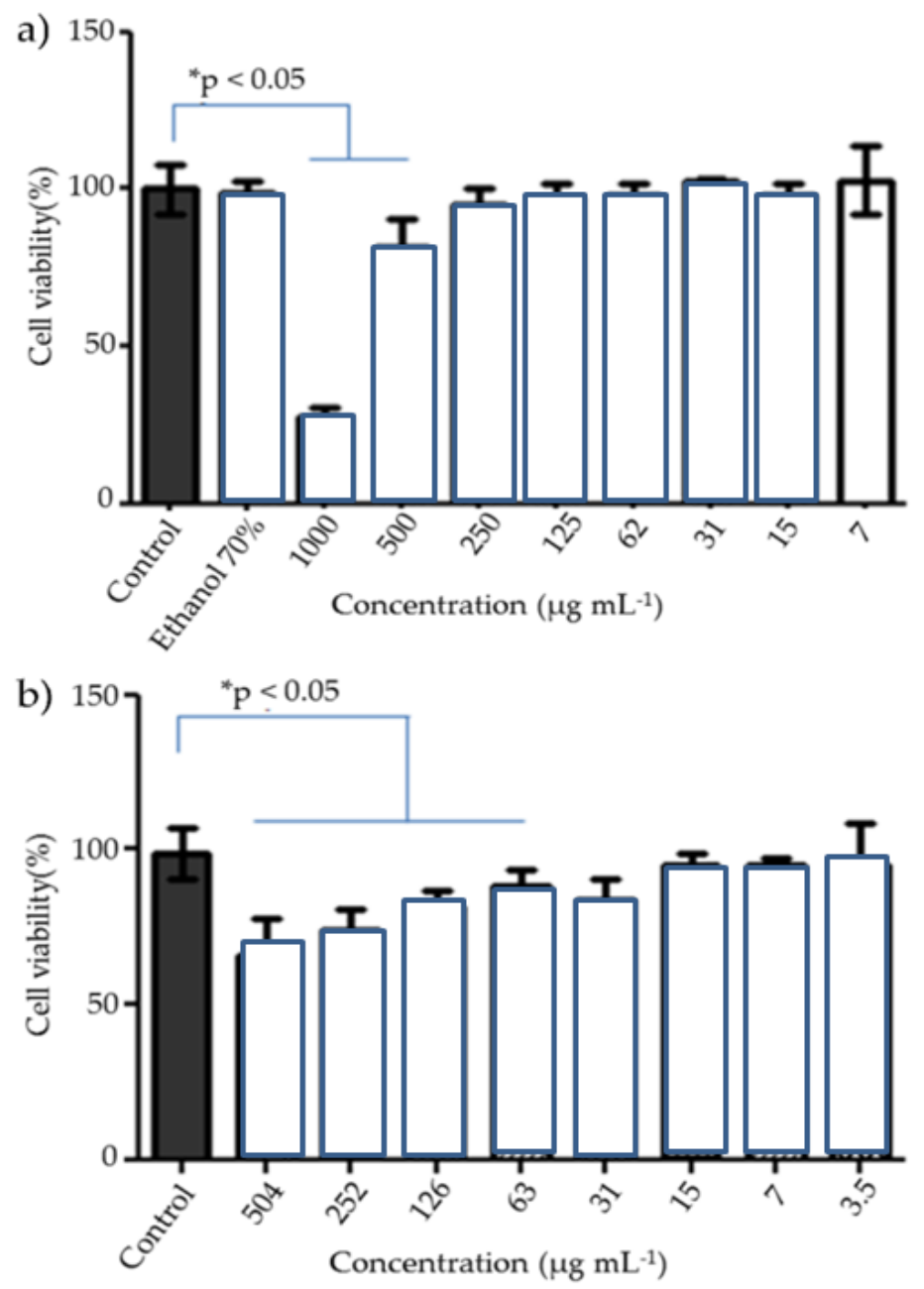


\section{Table $\mathbf{1}$ (on next page)}

Minimum Inhibitory Concentration (MIC) and Minimum Fungicidal Concentration (MFC) of C. ferrea extract, AgNPs and reference drugs.

Results of MIC and MFC were expressed in $\mu \mathrm{g} \mathrm{mL}^{-1}$. 
Table 1: Minimum Inhibitory Concentration (MIC) and Minimum Fungicidal Concentration (MFC) of $C$. ferrea extract, AgNPs and reference drugs.

\begin{tabular}{|c|c|c|c|c|c|c|c|c|}
\hline \multirow[t]{2}{*}{ Microorganisms } & \multicolumn{2}{|c|}{ Nystatin } & \multicolumn{2}{|c|}{$\begin{array}{c}\text { Amphotericin } \\
\text { B }\end{array}$} & \multicolumn{2}{|c|}{$\begin{array}{c}\text { C. ferrea (Tul) } \\
\text { Martius }\end{array}$} & \multicolumn{2}{|c|}{ AgNPs } \\
\hline & MIC & $\mathrm{MFC}$ & MIC & $\mathrm{MFC}$ & MIC & $\mathrm{MFC}$ & $\mathrm{MIC}$ & MFC \\
\hline $\begin{array}{c}\text { Candida } \\
\text { albicans ATCC } \\
10231\end{array}$ & 0.331 & 3.3 & 0.125 & 0.5 & 9.7 & 1,250 & 312.5 & 2,500 \\
\hline $\begin{array}{c}\text { Candida } \\
\text { glabrata } \mathrm{CCT} \\
0728\end{array}$ & 0.663 & 2.64 & 0.25 & 0.5 & 19.53 & 1,250 & 1,250 & 5,000 \\
\hline $\begin{array}{l}\text { Candida krusei } \\
\text { CCT } 1517\end{array}$ & 2.64 & 2.64 & 2 & 2 & 78 & $>5,000$ & 312.5 & 312.5 \\
\hline $\begin{array}{c}\text { Candida } \\
\text { guilliermondii } \\
\text { CCT } 1890\end{array}$ & 1,326 & 10.56 & 0.0312 & 0.0312 & 39.06 & 156.25 & 156.25 & 312.5 \\
\hline
\end{tabular}

Results of MIC and MFC were expressed in $\mu \mathrm{g} \mathrm{mL} \mathrm{m}^{-1}$. 